\title{
Application of Three Diagnostic Serologic Techniques to Detect of Dromedary Camel's Brucellosis
}

\author{
Mithal Kareem Abass Al-Hassani ${ }^{1}$ Hasanain AJ. Al-Gharban ${ }^{2}$
}

\author{
Luma foad Manher ${ }^{3}$
}

\author{
Dept. of Biological Science, Coll. of Education, Al-Qadisiyah University ${ }^{1}$ \\ Dept. of Internal \& Preventive Medicine / Coll. of Veterinary Medicine/ Wasit University ${ }^{2}$ \\ College of Enviromental Science AL-Qassim Green University ${ }^{3}$ \\ Email: Mithal.al-hassani@qu.edu.iq ${ }^{1}$ hghirban@uowasit.edu.iq ${ }^{2}$ \\ Received:-30/5/2017 \\ Accepted:-10/7/2017
}

\begin{abstract}
This study was aimed to evaluate the prevalence of brucellosis in camel by using of Rose-Bengal test (RBT), Standard-tube agglutination test (STAT) and competitive Enzyme-Linked immunosorbent assay (c-ELISA) for first time in Iraq. From some regions of Al-Qadisiyah governorate, a totally of 148 camels from both sexes were submitted for collection of blood samples, and the overall results showed that $8.78 \%, 4.1 \%$, and $12.84 \%$ of camels were seropositives by RBT, STAT and c-ELISA, respectively. In addition, the cross-classification results have been discussed as follow: by both c-ELISA and RBT, the seropositive result was $7.43 \%$, while, $5.41 \%$ by c-ELISA and $1.35 \%$ by RBT, only. Whereas, the positive result was $4.1 \%$ by both c-ELISA and STAT, while, $8.78 \%$ positive camels by c-ELISA, only. In regarding to sex factor, the positive results in female camels were $9.92 \%, 4.96 \%$ and $13.22 \%$; while in males, they were $3.7 \%, 0 \%$ and $11.11 \%$ by RBT, STAT and c-ELISA. In association to age factor, $\geq 4$ years group were reported $13.85 \%, 7.69 \%$ and $18.46 \%$, while in $1-4$ years group, they were $4.82 \%, 1.2 \%$ and $8.43 \%$ seropositive camels by RBT, STAT and c-ELISA, respectively. Statistically, the significant difference $(\mathrm{P} \leq 0.05)$ was reported among the total positive results and within the cross-classification results for applied serological tests. Also, the female camels were showed an infection rate more than males by RBT and STAT, whereas, both sexes were at a similar level of infection by c-ELISA. As well as, $>4$ years group were revealed on a high prevalence rate than 1-4 years group by all assays.
\end{abstract}

Keywords: Brucellosis, Dromedary Camel, Serologic techniques, Diagnostic, Application Physiology Classification QR1-502-75-9905 


\section{Introduction}

Brucellosis is a greatly zoonotic worldwide disease resulted by a Gram-negative bacterium, Brucella that classified at a risk group III by the WHO (1). The disease can cause substantial economical losses in livestock and sever or chronic debilitating illness in humans which obliged for a long period of treatment with a combination of antibiotics to get the cure (2). Although, the genus of Brucella has ten pathogenic species that infecting many primary and secondary hosts of domestic and wildlife animals as well as humans; but in camels, two species (B. abortus and B. melitensis) are implicated to be more frequent isolates (3). As reported by many previous studies, camels are very susceptible to brucellosis like other animals and their infection depends on the Brucella species that persist, abundantly, in their habitats (4). From public health view point, Brucella is considered to be as an occupational pathogen that affecting directly on slaughter house workers, butchers, as well as veterinarians (5). Camels can be infected, mostly, by ingestion during the grazing upon infected pasture or consuming of feedstuff or water supplies that contaminated by discharges, fatal membranes, and aborted fetuses of diseased animals; as well as to venereal and congenital transmission $(6,7)$.

There is neither a single diagnostic test available by which a bacterium can be identified as Brucella nor any signs and symptoms are specific for brucellosis. Therefore, the combination of more one diagnostic method is necessary for accurate diagnosis (8). Although, the reliable diagnosis can only made by direct isolation and detection of causative pathogen by culture, this procedure is complicated and constitute a large infection risk (9). Also, this method is impractical for regular screening of large population and cannot be used as criteria for control and eradication of disease (10, 11). Many serological techniques were applied for the evaluation of specific Brucella-antibodies (IgG and $\operatorname{IgM}$ ) in humans and animals, among which they have a key role in the rapid and proper diagnosis (12). Rose-Bengal test and Standard-tube agglutination test are used, largely, for long period as the tests of field with reasonable sensitivity and an acceptable, to some extent, specificity for monitoring of infection because of their easily, safety to use and quit inexpensively (13). ELISA is, relatively, simple to perform and provided a practical advantage in detecting a prevalence of infection. In addition, it's posses a very high sensitivity and specificity that can reach to $100 \%$, ready to be given an automated results, rapidly and accurately (14). 
The aims of this study were carried out to evaluate the prevalence of camel brucellosis by application of three serological assays including the Rose-Bengal test (RBR), Standard-Tube agglutination test (STAT) and ELISA on serum samples of camels.

and from some areas related to Al-Qadisiyah governorate, a totally of 148 camels with more than one year of age and from both sexes were submitted for this study. From each one, $10 \mathrm{ml}$ of blood samples were drained form jugular vein by using a

\section{Serological assays}

\section{Rose-Bengal test (RBT)}

According to manufacturer's instruction (Bioveta/Czech), the serum samples and antigen bottle were left at $37^{\circ} \mathrm{C}$ for 30 minutes. The antigen bottle was shaken, gently, to ensure that suspension was homogenous. Then, $30 \mu \mathrm{L}$ of antigen with $30 \mu \mathrm{L}$ of serum samples were placed into each square of a plate, mixing with a spreader, rotated manually for four minutes, and the results was considered as positive for any degree of agglutination. With each set of test sera, the positive and negative controls were applied.

\section{Standard-Tube Agglutination Test} (STAT)

\section{Materials and Methods}

\section{Samples collection}

During the period from May to July/2016

vacationer tube without anticoagulant, which centrifuged at $3000 \mathrm{rpm}$ for 15 minutes for serum separation. The serum samples were packaged in a numbered $1 \mathrm{ml}$ eppendorfs and kept at $-20^{\circ} \mathrm{C}$ until be used.

According to manufacturer's instruction (Bioveta/Czech), the serum samples and an antigen bottle were left at $37^{\circ} \mathrm{C}$ for 30 minutes. The doubling dilution of tested serum had been done, starting from 1:5, with $0.5 \%$ of phenol saline in ten tubes. The antigen bottle was shaken, well, and $50 \mu \mathrm{L}$ of antigen was added to each tube and mixed by rolling in between the palms. At the same time, five tubes were prepared positive and negative controls by using of an antigen in $0.5 \%$ phenol saline. All test and controls tubes were incubated in a water bath at $37^{\circ} \mathrm{C}$ for 24 hours, and the received results of serum samples were compared with control tubes as detailed in (Table 1). 
Table (1): Interpretation of STAT results

\begin{tabular}{|c|c|c|c|c|}
\hline $\begin{array}{c}\text { Control } \\
\text { Tubes }\end{array}$ & $\begin{array}{c}\text { 0.5\% Phenol } \\
\text { Saline }\end{array}$ & Antigen & $\begin{array}{c}\text { Agglutination } \\
\text { Degree }\end{array}$ & Interpretation \\
\hline Tube 1 & - & $2 \mathrm{ml}$ & No - Agglutination & Negative \\
\hline Tube 2 & $1.25 \mathrm{ml}$ & $0.75 \mathrm{ml}$ & $25 \%$ - Agglutination & \multirow{4}{*}{ Positive } \\
\hline Tube 3 & $1.50 \mathrm{ml}$ & $0.50 \mathrm{ml}$ & $50 \%$ - Agglutination & \\
\hline Tube 4 & $1.75 \mathrm{ml}$ & $0.25 \mathrm{ml}$ & $75 \%$ - Agglutination & \\
\hline Tube 5 & $2 \mathrm{ml}$ & - & $100 \%$ - Agglutination & \\
\hline
\end{tabular}

\section{Competitive Enzyme-Linked}

\section{Immunosorbent Assay (c-ELISA)}

The qualitative camel Brucella antibody IgG (B-IgG) ELISA kit (Cat. No: MBS059216 / MyBioSource / Canada) was used in this study. The serum samples and ELISA kit were left at $37^{\circ} \mathrm{C}$ for 30 minutes, and according to manufacturer's instructions, the assay was performed and read at a wave length of $450 \mathrm{~nm}$ optical density (OD) by using of a microplate photometer ELISAreader (BioTek-USA). The test validity and results interpretation were discussed as in (Table 2).

Table (2): Test validation and interpretation of ELISA results

\begin{tabular}{|c|c|c|c|}
\hline \multirow{2}{*}{1} & \multirow{2}{*}{ Test Validity } & Positive $_{\text {Control }}$ & OD $\geq 1$ \\
\cline { 3 - 4 } & & Negative $_{\text {Control }}$ & OD $\leq 0.15$ \\
\hline 2 & Critical $_{\text {CUT OFF }}$ & Criteria & Average of Negative Controls +0.15 \\
\hline \multirow{2}{*}{3} & \multirow{2}{*}{ Results } & Positive $_{\text {Samples }}$ & OD $_{\text {Samples }} \geq$ Critical $_{\text {CUT OFF }}$ \\
\cline { 3 - 4 } & & Negative $_{\text {Samples }}$ & OD $_{\text {Samples }}<$ Critical $_{\text {CUT OFF }}$ \\
\hline
\end{tabular}

\section{Statistical analysis}

All data were tabled and analyzed by a computerized Microsoft Excel Word (2013) and IBM/SPSS programs (v.23). Descriptive statistics and Chi-square $\left(X^{2}\right)$ test were used

\section{Results}

In (Table 3) that dealt with an application of three serological tests on a totally of 148 to detect the significant differences $(\mathrm{P} \leq 0.05)$ between the results of serological assays that applied in this study (15).

serum camel's samples, and revealed on 13 (8.78\%), $6(4.1 \%)$, and 19 (12.84\%) positive 
camels by RBT, STAT and c-ELISA, respectively.

Table (3): Total results of serological assays on 148 camels' serum samples

\begin{tabular}{|c|c|c|c|}
\hline \multicolumn{2}{|c|}{ Serological Assays } & Seropositives & Seronegatives \\
\hline $\mathbf{1}$ & RBT & $\mathbf{1 3}(\mathbf{8 . 7 8} \%)^{\mathrm{b}}$ & 135 \\
\hline $\mathbf{2}$ & STAT & $\mathbf{6 ( 4 . 1 \% ) ^ { \mathrm { c } }}$ & 142 \\
\hline $\mathbf{3}$ & c-ELISA & $\mathbf{1 9 ( 1 2 . 8 4 \% ) ^ { \mathrm { a } }}$ & 99 \\
\hline
\end{tabular}

Variations in small letters, vertically, referred to significant differences at $\mathrm{P} \leq 0.05$

The cross-classification of positive and negative results by the adopted serological tests was discussed as follow: by both cELISA and RBT, there were a totally of 11 (7.43\%) positive samples and $127(85.81 \%)$ negative samples; while, 2 (1.35\%) samples were positive by RBT and negative by cELISA, and $8(5.41 \%)$ samples were positives by c-ELISA and negatives by RBT (Table 4).

Table (4): Cross-classification results of c-ELISA and RBT in total 148 camels

\begin{tabular}{|c|c|c|c|}
\cline { 2 - 3 } \multicolumn{1}{c|}{} & \multicolumn{2}{c|}{ Results of RBT } & \multirow{2}{*}{ Total } \\
\hline Results of c-ELISA & Positive & Negative & 19 \\
\hline Positive & $11(7.43 \%)^{\mathrm{Ba}}$ & $8(5.41 \%)^{\mathrm{Bb}}$ & 129 \\
\hline Negative & $2(1.35 \%)^{\mathrm{Bb}}$ & $127(85.81 \%)^{\mathrm{Aa}}$ & $\mathbf{1 4 8}$ \\
\hline Total & 13 & 135 & \\
\hline
\end{tabular}

Variations in large and small letters, horizontally and vertically, referred to significant differences at $P \leq 0.05$

Also, by both c-ELISA and STAT, there $13(8.78 \%)$ samples were positive by cwere $6(4.1 \%)$ and $129(87.16 \%)$ positive ELISA and negative by STAT (Table 5). and negative samples, respectively; while,

Table (5): Cross-classification results of c-ELISA and STAT in 148 camels

\begin{tabular}{|c|c|c|c|}
\cline { 2 - 3 } \multicolumn{1}{c|}{} & \multicolumn{2}{c|}{ Results of STAT } & \multirow{2}{*}{ Total } \\
\hline Results of c-ELISA & Positive & Positive & 49 \\
\hline Positive & $6(4.1 \%)^{\mathrm{Ba}}$ & $13(8.78 \%)^{\mathrm{Ab}}$ & 99 \\
\hline Negative & $0(0 \%)^{\mathrm{Bb}}$ & $129(87.16 \%)^{\mathrm{Aa}}$ & $\mathbf{1 4 8}$ \\
\hline Total & 6 & 142 & . \\
\hline
\end{tabular}

Variations in large and small letters, horizontally and vertically, referred to significant differences at $\mathrm{P} \leq 0.05$

In (Table 6) that dealt with an association of obtained risk factors (sex and age) with the serological assays (RBT, STAT, and cELISA). seropositive results by the applied

Table (6): An association of risk factors to seropositive results by the applied assays 


\begin{tabular}{|l|c|c|c|c|c|c|}
\hline \multirow{2}{*}{1} & \multirow{2}{*}{ Sex } & Male & 27 & $1^{(3.7 \%)^{\mathrm{Bb}}}$ & $0(0 \%)^{\mathrm{Cb}}$ & $3(11.11 \%)^{\mathrm{Ab}}$ \\
\cline { 3 - 7 } & Female & 121 & $12(9.92 \%)^{\mathrm{Ba}}$ & $6(4.96 \%)^{\mathrm{Ca}}$ & $16(13.22 \%)^{\mathrm{Ab}}$ \\
\hline \multirow{2}{*}{2} & \multirow{2}{*}{ Age } & $\mathbf{1 - 4}$ Years & 83 & $4(4.82 \%)^{\mathrm{Bb}}$ & $1(1.2 \%)^{\mathrm{Cb}}$ & $7(8.43 \%)^{\mathrm{Ab}}$ \\
\cline { 3 - 7 } & $\geq 4$ Years & 65 & $9(13.85 \%)^{\mathrm{Ba}}$ & $5(7.69 \%)^{\mathrm{Ca}}$ & $12(18.46 \%)^{\mathrm{Aa}}$ \\
\hline
\end{tabular}

Variation in large and small letters, horizontally and vertically, between groups of each factor referred to significant differences at a level of $(\mathbf{P} \leq \mathbf{0 . 0 5})$

$(3.7 \%), 0(0 \%)$, and $3(11.11 \%)$, while in

In (Figure 1): In regarding to sex factor, the 121 females, $12(9.92 \%), 6(4.96 \%)$, and 16 seropositive results in 27 males were 1

by

RBT,

STAT, and c-ELISA

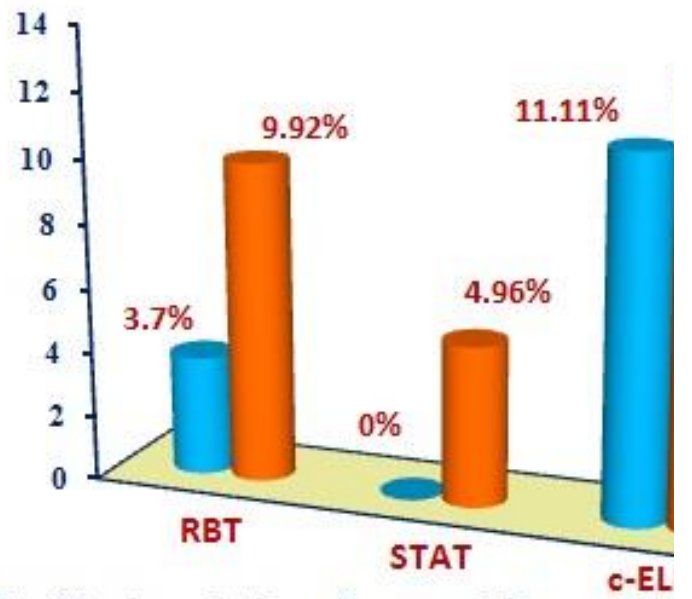

Fig. (1): Association of seropositive results

In (Figure 2): In regarding to age factor, the positive results in 83 camels with (1-4) years age old were $4(4.82 \%), 1(1.2 \%)$, and 7 $(8.43 \%)$, whereas in 65 camels with $\geq 4$ respectively. years age old, the positive results were 9 (13.85\%), 5 (7.69\%), and $12(18.46 \%)$ by RBT, STAT, and c-ELISA,

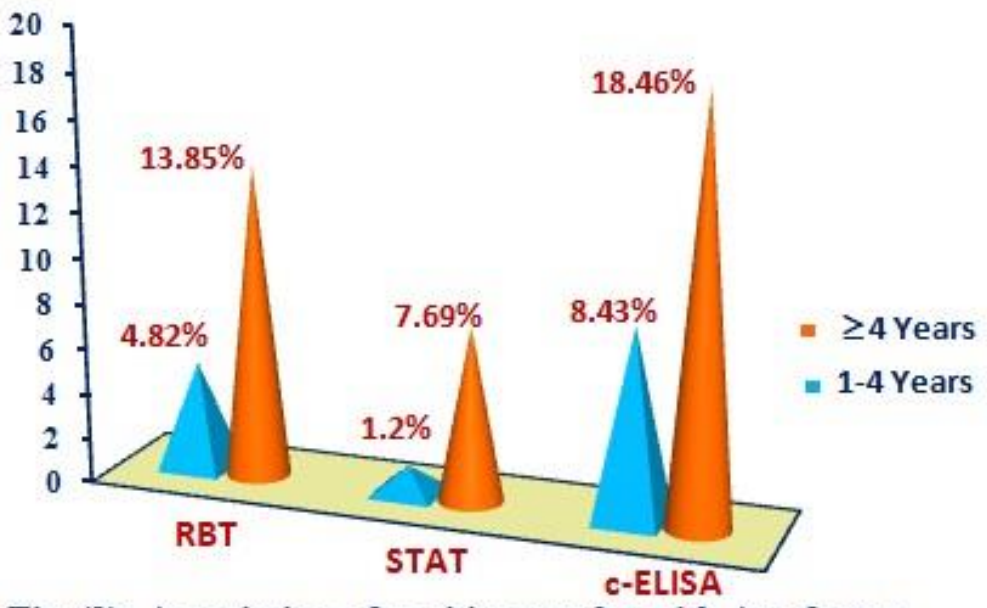

Fig. (2): Association of positive results with Age factor 


\section{Discussion}

Although, most countries have been attempted to provide the sources for eradicating brucellosis from the domestic animals populations, it's still widespread as an agriculture disease, and several cases of human brucellosis have been reported every year in areas where the disease has not eliminated in livestock (16). The economic and public health impact of Brucella remain of particular concern as the disease posses a barrier for trading of animals and animal's products that represented a public health hazard causing an impediment to free-animals movement (17). In this study, the seroprevalence of antibodies to camel brucellosis was estimated by using three serological techniques, for first time in Iraq, which revealed on $8.78 \%$ by RBT, $4.1 \%$ by STAT, and $12.84 \%$ by ELISA (Table 3 ). Also, the cross-classification results of ELISA with RBT (Table 4) and ELISA with STAT (Table 5) were showed a significant difference between their seropositive and seronegative camels. In Iraq, by using of RBT only, the prevalence of Brucella antibodies was evaluated to be $3.03 \%$ (18) and $6.73 \%$ (19), while globally, the seroprevalence of camel brucellosis reported a greatly different data between regions,

countries and the diagnostic methodologies, which had been ranged from $0 \%$ to $51 \%$ (19, 20, 21). Several studies have been done worldwide by using of many serological techniques to evaluate the prevalence of camel brucellosis and to explain the caused that lead to the variable results between these techniques $(23,24)$. Therefore, the selection of a gold standard test was represented as one of the most important and difficult steps in studies that dealt with diagnostic tests. In brucellosis, a gold standard test is a bacterial isolation of Brucella spp. from body fluids or tissue specimens, which required a long cultivation period and, in often, resulted on an unsuccessful of culture $(25,26)$. Some studies believed that the findings of a true gold standard have not achievable, and for this cause, the finding of diagnostic tests that able to completely differentiate between the infected and healthy individuals is impossible. It's quite obvious that the different criteria in detection of infected animals could affect the study results (27). 
In regarding to $\mathrm{RBT}$ that developed as a diagnostic method having the rapidity, simplicity in its performance, and low cost with absence of infection's risk to laborers; though, the disadvantages of this test involved a high possibility of false negative results due to presence of blocking antibodies, in addition to the low specificity particularly in endemic areas due to presence of high antibody prevalence in the healthy population $(28,29)$. In respecting to STAT that represented as the first developed serological test applied in diagnosis of brucellosis in dependently on bacterial antigen agglutination under neutral $\mathrm{pH}$, the test is slow in an antibody-antigen reaction, required high skills and has a very low specificity (30). In countries where there was a strategy for using of vaccination, a considerable lack of specificity in results of RBT and STAT that might be occurred due les with a high sensitivity and specificity varies between (92-100\%) and (90-99\%), respectively (34). In addition, the assay was characterized by its capability for differentiating of a vaccine antibody response from actual infections, and the false-negative or false-positive results might be resulted due to inequalities between the commercial ELISA kits or presence of rheumatoid factors that occurred in some to a cross-reaction (31). Hence, in endemic areas, the diagnosis of brucellosis must be supported with a high sensitivity and specificity technique to avoid or reduce the faults. However, as reported by several previous studies, ELISA demonstrated a high specificity where compared to other diagnostic techniques, especially, in endemic regions or countries $(32,33)$. Also, the technique is excellent in screening of large populations for Brucella antibodies ((IgM and $\operatorname{IgG}$ ) and for differentiation between acute and chronic phases of the disease. Also, it's the test of choice in complicated cases under a high clinical suspicion, particularly, when other tests displayed on negative results (23). The kit of ELISA that used in this study, has a smooth Brucella lipopolysaccharide (LPS) as antigen for detection of anti-Brucella in serum samp

chronic cases of suppurative brucellosis (35).

In relation to sex factor, $\mathrm{RBT}$ and STAT were reported that the female camels were having a high seropositive prevalence in their Brucella antibodies than males, while, c-ELISA had been showed that the seroprevalence were without significant differences between both sexes (Table 6, Figure 1). Several studies have been reported 
that the female camels were more susceptible to brucellosis than males and this could be attributed to the fact that the females have more physiological stresses than males or due to presence of erythritol in females, only $(36,37)$. Other studies were reported an equal distribution of Brucella antibody between both sexes $(38,39)$. Even though, the number of breeding males kept by the pastoralists in the camel herds of the present study was small on which random sampling method was applied and this predictably bias the statistical analysis.

Although, all age groups were susceptible to brucellosis, young animals tend to be more resistant to brucellosis than adult that have an increasing in their susceptibility with increasing of age and this could be interpreted to the facts that the sex hormone and erythritol, which stimulate the growth and multiplication of Brucella organisms, tend to increase with age and sexual maturity (40, 41). With advancing of age, immunity against various infections could be depressed due to different causes such as stress factors and frequent exposures to diseased pathogens (42).

In conclusion, c-ELISA was demonstrated a high effectiveness in detection of Brucella antibodies than RBT and STATA, and can be used as a test of gold standard for diagnosis of camel brucellosis. Also, the study was reported that age and sex might play an important role in an incidence of infection among camels.

\section{References}

1. Agasthya AS., Isloor S., and Prabhudas, K. (2007). Brucellosis in high risk group individuals. Indian journal of medical microbiology, 25(1), 28.

2. Young, EJ. (2006). Brucella spp. Principles and Practice of Clinical Bacteriology, 2nd ed. John Wiley \& Sons Ltd, West Sussex, England, Pp: 265-272.

3. Godfroid J., Cloeckaert A., Liautard JP., Kohler S., Fretin D., Walravens K., and Letesson, JJ. (2005). From the discovery of the Malta fever's agent to the discovery of a marine mammal reservoir, brucellosis has continuously been a reemerging zoonosis. Veterinary research, 36(3), 313-326.

4. Gwida M., El-Gohary A., Melzer F., Khan I., Rösler U., and Neubauer, H. (2012). Brucellosis in camels. Research in Veterinary Science, 92(3), 351-355.

5. Gul ST., and Khan, A. (2007). Epidemiology and epizootology of brucellosis: A review. Pakistan Veterinary Journal, 27(3), 145. 
6. Memish ZA., and Balkhy, HH. (2004). Brucellosis and international travel. Journal of travel medicine, 11(1), 49-55.

7. Constable PD., Hinchcliff KW., Done SH., and Gruenberg, W. (2016). Veterinary Medicine: A textbook of the diseases of cattle, horses, sheep, pigs and goats. Eleven Edit., Elsevier Health Sciences, Pp: 1761-1784.

8. Al Dahouk S., and Nöckler, K. (2011). Implications of laboratory diagnosis on brucellosis therapy. Expert review of antiinfective therapy, 9(7), 833-845.

9. Bosilkovski, M. (2015). Brucellosis: It is not only Malta. In Zoonoses-Infections Affecting Humans and Animals, Springer Netherlands, Pp: 287-315.

10. Houpikian P., and Raoult, D. (2002). Diagnostic methods: current best practices and guidelines for identification of difficult-to-culture pathogens in infective endocarditis. Infectious disease clinics of North America, 16(2), 377-392.

11. Çiftci A., İça T., Savaşan S., Sareyyüpoğlu B., Akan M., and Diker, KS. (2017). Evaluation of PCR methods for detection of Brucella strains from culture and tissues. Tropical animal health and production, 49(4), 755-763.

12. Chinyoka S., Dhliwayo S., Marabini L., Dutlow K., Matope G., and Pfukenyi,
DM. (2014). Serological survey of Brucella canis in dogs in urban Harare and selected rural communities in Zimbabwe. Journal of the South African Veterinary Association, 85(1), 01-05.

13. Rahman AA., Saegerman C., Berkvens D., Fretin D., Gani MO., Ershaduzzaman M., and Emmanuel, A. (2013). Bayesian estimation of true prevalence, sensitivity and specificity of indirect ELISA, Rose Bengal Test and Slow Agglutination Test for the diagnosis of brucellosis in sheep and goats in Bangladesh. Preventive Vet. Medicine, 110(2), 242-252.

14. Fiasconaro M., Mannelli A., Rappazzo E., Aronica V., Ferrara MC., Vesco G., and Presti, VD. (2015). Field evaluation of fluorescence polarization assay, and comparison with competitive ELISA for the detection of antibodies against Brucella melitensis in sheep in Sicily, Italy. Small Ruminant Research, 130, 252-255.

15. Petrie A., and Watson, P. (2006). Statistics for Veterinary and Animal Science, Second Edition. Ames: Blackwell Publishing, Pp: 312.

16. Addis, M. (2015). Public Health and Economic Importance of Brucellosis: A Review. Public Health, 5(7), 68-83. 
17. Bronner A., Hénaux V., Fortané N., Hendrikx P., and Calavas, D. (2014). Why do farmers and veterinarians not report all bovine abortions, as requested by the clinical brucellosis surveillance system in France? BMC veterinary research, 10(1), 93.

18. Yawoz M., Jaafar SE., Salih AI., and Abdullah, MH. (2012). A serological study of brucellosis in camels south of Kirkuk, Iraq. Iraqi J. of Veterinary Sciences, 26(2), 105-107.

19. Al-Rodhan MA., Ni'ma AJ., and AlNasrawi, HA. (2006). Serological study of brucellosis in camels in Al-Diwanya province. Al-Qadisiyah Journal of Veterinary Science, 2 (5), 7-11.

23. Ducrotoy MJ., Bertu WJ., Ocholi RA., Gusi AM., Bryssinckx W., Welburn S., and Moriyon, I. (2014). Brucellosis as an emerging threat in developing economies: lessons from Nigeria. PLoS Negl Trop Dis, 8(7), e3008.

24. Khan F., Khawar R., Ansari Z., Syriac G., Muttathpaily N., Raghavan R., and Wernery, U. (2016). Comparative performance study of four different serological tests for the diagnosis of dromedary brucellosis. Journal of Camel Practice and Research, 23(2), 213-217.
20. Dawood, HA., (2008). Brucellosis in camels (Camelus dromedorius) in the south province of Jordan. American Journal of Agricultural and Biological Sciences, 3 (3), 623-626.

21. Gessese AT., Mulate B., Nazir S., and Asmare, A. (2014). Seroprevalence of Brucellosis in Camels (Camelus dromedaries) in South East Ethiopia. Journal of Veterinary Scientific Medical Diagnosis, 3, 1, 2.

22. Madu GA., Adama OR., James BW., Hassan M., Lubabatu I., Esther M., and Gulak, WH. (2016). Sero-prevalence of camel brucellosis in three abattoirs of Northern Nigeria. Journal of Veterinary Medicine and Animal Health, 8(3), 15-20.

25. Álvarez J., Perez A., Bezos J., Marqués S., Grau A., Saez JL., and Domínguez, L. (2012). Evaluation of the sensitivity and specificity of bovine tuberculosis diagnostic tests in naturally infected cattle herds using a Bayesian approach. Veterinary microbiology, 155(1), 38-43.

26. Pérez-Sancho M., García-Seco T., Arrogante L., García N., Martinez I., Diez-Guerrier A., and Alvarez, J. (2013). Development and evaluation of an IS711based loop mediated isothermal amplification method (LAMP) for detection of Brucella spp. on clinical 
samples. Research in veterinary science, 95(2), 489-494.

27. Peeridogaheh H., Golmohammadi MG., and Pourfarzi, F. (2013). Evaluation of ELISA and Brucellacapt tests for diagnosis of human Brucellosis. Iranian J. of microbiology, 5(1), 14-18.

28. Munoz PM., Marin CM., Monreal D., Gonzalez D., Garin-Bastuji B., Díaz R., and Blasco, JM. (2005). Efficacy of several serological tests and antigens for diagnosis of bovine brucellosis in the presence of false-positive serological results due to Yersinia enterocolitica O: 9. Clin. \& Diagnostic Lab. Immunology, 12(1), 141-151.

29. Ruiz-Mesa JD., Sanchez-Gonzalez J., Reguera JM., Lopez-Palmero S., and Colmenero, JD. (2005). Rose Bengal test: diagnostic yield and use for the rapid diagnosis of human brucellosis in emergency departments in endemic areas. Clinical Microbiol. \& infection, 11(3), 221-225.

30. Ariza J., Pigrau C., Canas C., Marron A., Martinez F., Almirante B., and Pahissa, A. (2001). Current understanding and management of chronic hepatosplenic suppurative brucellosis. Clinical infectious diseases, 32(7), 1024-1033.
31. Nielsen K., and Yu, WL. (2010). Serological diagnosis of brucellosis. Prilozi, 31(1), 65-89.

32. Wang X., Wang Y., Ma L., Zhang R., De Y., Yang X., and Wu, Q. (2015). Development of an improved competitive ELISA based on a monoclonal antibody against lipopolysaccharide for the detection of bovine brucellosis. BMC veterinary research, 11(1), 118.

33. Getachew T., Getachew G., Sintayehu G., Getenet M., and Fasil, A. (2016). Bayesian Estimation of Sensitivity and Specificity of Rose Bengal, Complement Fixation, and Indirect ELISA Tests for the Diagnosis of Bovine Brucellosis in Ethiopia. Veterinary Medicine International, 2016.

34. Geresu MA., and Kassa, GM. (2016). A review on diagnostic methods of brucellosis. Journal of Veterinary Science and Technology, 7(3), 1-8.

35. del Pozo JS., Ortuno SL., Navarro E., and Solera, J. (2014). Detection of IgM antibrucella antibody in the absence of IgGs: a challenge for the clinical interpretation of Brucella serology. PLoS Negl Trop Dis, 8(12), e3390.

36. Refai, M. (2002). Incidence and control of brucellosis in the Near East region. Veterinary microbiology, 90(1), 81-110. 
37. Baloch AS., Rasheed A., Rind R., Sahito JK., Buriro R., Ayoob MF., and Dewani, P. (2017). Seroprevalence of 38. Ullah S., Jamil T., Mushtaq M., and Saleem, M. (2015). Prevalence of brucellosis among camels in district Muzaffargarh, Pakistan. Journal of Infection and Molecular Biology,3,52-56.

39. Al-Majali AM., Al-Qudah KM., AlTarazi YH., and Al-Rawashdeh, OF. (2008). Risk factors associated with camel brucellosis in Jordan. Trop. Animal H. and production, 40(3), 193-200.

40. Hadush A., Pal M., Kassa T., and Zeru, F. (2013). Sero-epidemiology of camel brucellosis in the Afar region of
Brucellosis in Camels in Sindh, Pakistan. Pakistan Journal of Zoology, 49(1), 367369.

Northeast Ethiopia. Journal of Veterinary Medicine and Animal Health, 5(9), 269275.

41. Rahman, AKM. (2015). Epidemiology of brucellosis in humans and domestic ruminants in Bangladesh. Doctoral dissertation, Université de Liège, Liège, Belgique, Chapter 10, Pp: 151.

42. Adamu SG., Tijjani AO., Adamu NB., and Ali, S. (2014). Serological survey for Brucella antibodies in one-humped camel (Camelus dromedarius) herds in NorthEastern Nigeria. Veterinary World, 7(3). 


\title{
استعمال ثلاث تقنيات مصلية
}

\author{
تشخيصية لأكتشاف داء بروسيلا الجمال العربية \\ مثال كريم عباس الحسني ${ }^{1}$ حسنين عبد الحسين جعفر الغربان² لمى فؤاد منحر 3

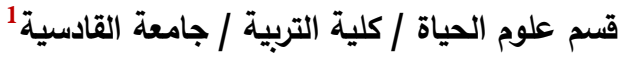

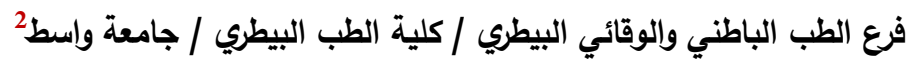 \\ جامعة القاسم الخضراء / كلية علوم البيئة3

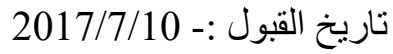 \\ تاريخ الاستلام:- 2017/5/30
}

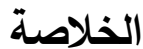

هدفت الدراسة الحالية الى تقييم الانتشار المصلي لداء البروسيلا في الجمال باستخدام اختبار وردية البنغال (RBT) ، اختبار تلازن

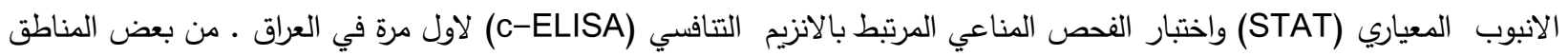

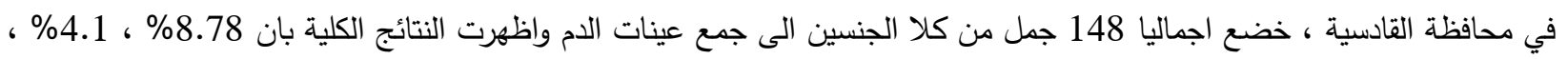

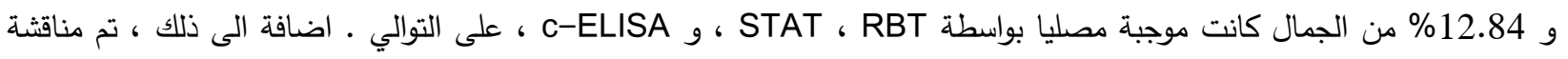

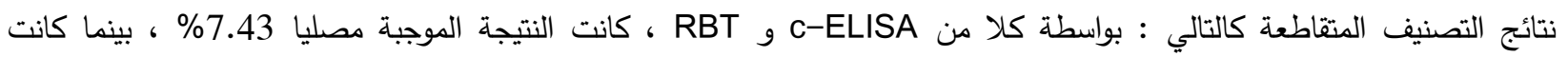

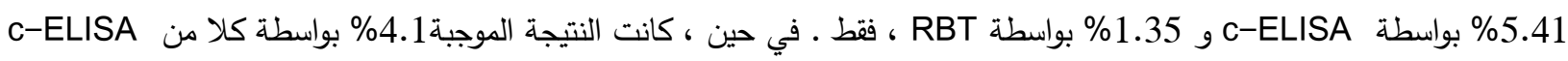

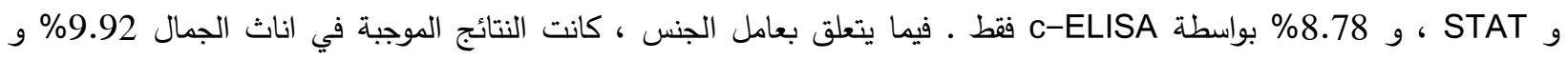

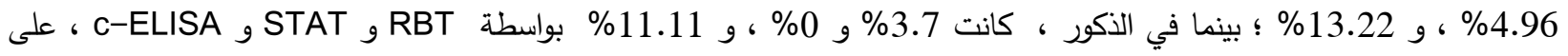

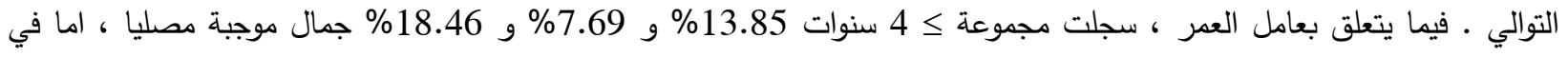

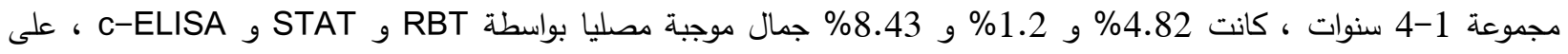

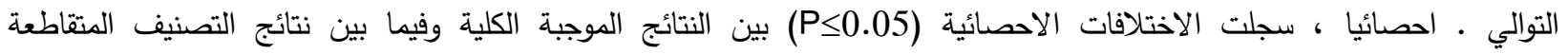

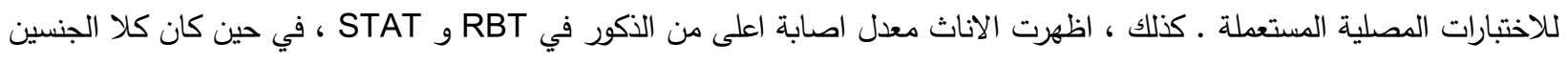

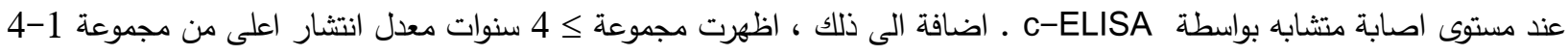
سنوات بواسطة كل الاختبارات .

الكلمات المفتاحية : داء البروسيلا ، جمال عربية ، تقنيات مصلية ، تثخيصية ، استعمال 